\title{
Marco Cristini*
}

\section{Diplomacy at the End of the World: Theoderic's Letters to the Warni and Hesti}

\author{
https://doi.org/10.1515/klio-2020-0303
}

Summary: Theoderic's diplomacy with distant peoples has often been considered as a kind of 'Realpolitik' chiefly aimed at military or strategical purposes, but the symbolic importance of two embassies from the Warni and Hesti should be taken into consideration more carefully. The king aimed to convince his subjects and neighbours that he was the rightful heir of the Roman emperors by following a subtle policy of imitatio Imperii. He also used diplomacy to achieve this goal and took advantage of two embassies from remote peoples of Northern Europe in order to imitate both Augustus and contemporary emperors, who prided themselves upon receiving envoys from far-away lands.

Keywords: Cassiodorus, Theoderic, Ostrogoths, Late Antique Universalism, Augustus

\section{Introduction}

Ille ego sum mundi quondam sine fine viator ("I am that former, ceaseless wayfarer of the world"). This hexameter was engraved at the beginning of Senarius' epitaph, an inscription which provides important insights into Ostrogothic diplomacy. ${ }^{1}$ Senarius was not overstating his biography, as he went on twenty-five embassies for his king, Theoderic the Great, traversing both Europe and Asia. ${ }^{2}$ Such long and frequent missions were not unusual for Ostrogothic ambassadors ${ }^{3}$, since Theoderic's diplomatic network stretched as far as

\footnotetext{
1 The epitaph was published by Pierre Pithou in 1590; unfortunately, its provenance is unknown, see Pithou 1590, $108 \mathrm{f}$. and 463; see also Gillett 2003, 290. The epitaph can be read in Mommsen 1894, 499 (s.v. Senarius); PLRE 2, 988; Gillett 2003, 195.

2 See PLRE 2, 988-989; Amory 1997, 413; PChBE 2, 2020-2021; Gillett 2003, 190-219; Becker 2013, $129 \mathrm{f}$.

3 On ambassadors traveling to remote lands, see Nechaeva 2007. On ambassadors and embassies in Late Antiquity, more in general, see Gillett 2003; Becker - Drocourt 2012.
}

*Kontakt: Marco Cristini, E-Mail: marco.cristini@sns.it

ว Open Access. (๑) 2021 Marco Cristini, published by De Gruyter. (ङ) BY This work is licensed under the Creative Commons Attribution 4.0 International License. 
Denmark and the Baltic shores, and he sought to strengthen it throughout his reign. ${ }^{4}$

Diplomacy played a fundamental role in Theoderic's foreign policy from the very beginning of his rule over Italy. ${ }^{5}$ The emperor Zeno had sent him to the West in 488 in order to remove Odoacer from power and free Constantinople from the threat posed by the Ostrogoths, who had recently plundered Thrace. It is unclear whether they reached a comprehensive deal about the future position of Theoderic or not, because our main source, the Excerpta Valesiana, is very vague ${ }^{6}$, reporting only that Theoderic should have ruled the country in the emperor's stead until he arrived. ${ }^{7}$ Zeno was by no means certain of an Ostrogothic victory, so he did not define the details of Theoderic's rule over Italy in a clear way. The king, however, took Ravenna, killed Odoacer and tried to secure imperial recognition, which was granted only five years later, after three embassies. ${ }^{8}$ There is no space here for a full discussion about the reasons for this delay, but suffice it to say that Theoderic was not in a strong position. He probably led only 40,000 Ostrogoths to Italy, that is, more or less 10,000 fighting men, and many died during the struggle against Odoacer. ${ }^{9}$ Theoderic was able to conquer his enemy only thanks to the Visigoths, who helped him to rout Odoacer's army. ${ }^{10}$ Meanwhile, both Burgundians and Vandals took advantage of the war to plunder Sicily and Northern Italy, knowing that the Ostrogoths could not stop them. ${ }^{11}$ For these reasons, the

4 On Theoderic's foreign policy, see Wolfram 2009, 306-327, and Last 2013.

5 Theoderic's reign has been studied by Moorhead 1992, and, more recently, Wiemer 2018. A good introduction to Ostrogothic Italy is provided by Arnold et al. 2016. The reference work on the Goths is still Wolfram 2009, but see also Burns 1984, and Heather 1996.

6 Jones 1962 argues that Theoderic invaded Italy as patricius and magister militum, but then had himself proclaimed king, and believes that the treaty signed in 488 is comparable with the agreement between Theodahad and Peter the Patrician (Prok. BG 1.6); see also Prostko-Prostyński 1994, 103-129. Thompson 1982, 73, is more skeptical: "The constitutional position of Theoderic [...] was never defined.” See also Moorhead 1984; König 1994; in general, also Kohlhas-Müller 1995.

7 Exc. Val. 49: dum adveniret, tantum praeregnaret. For other sources about this agreement, although with less precision, see Marc. Com. Chron. a. 488; Iord. Get. 291, Rom. 348; Prok. BG 1.1.10-12; Eust. Epiph. fr. 4 Müller (FGH 4, 140-141); Teoph. Chron. AM 5977; Paul. Diac. Hist. Rom. 15.14.

8 Exc. Val. 64, commented by König 1994, 156-158.

9 See Burns 1978. Usually, the Ostrogoths who came to Italy have been estimated to number ca. 100,000 (thus, 20-25,000 warriors); see already Schmidt 1905, 152; more recently Heather 1996, 236; Wolfram 2009, 279; Wiemer 2018, 180. However, these estimates are often based upon Prok. BV 1.8.12, a passage which is not trustworthy, see Cristini 2017.

10 Exc. Val. 53; see Wiemer 2018, 185-186.

11 Burgundians: Ennod. vita Epiph. 136-176, Ennod. pan. 54; Cassiod. var. 12.28.2; Paul. Diac. Hist. Rom. 15.17; see also Favrod 1997, 302-304. Vandals: Cassiod. Chron. a. 491; Ennod. pan. 70; see also Steinacher 2016, $277 \mathrm{f}$. 
emperor decided to wait until Theoderic's power was consolidated and only then did he grant his recognition.

Ostrogothic rule rested on three foundations: co-operation with Italian senatorial aristocracy, good-will between Ravenna and Constantinople, and peace among barbarian kingdoms. ${ }^{12}$ In order to achieve these aims, Theoderic pursued an elaborate policy of imitatio Imperii, which enabled him to be perceived by both subjects and neighbours not as a barbarian king, but as a worthy successor of the Roman emperors. The Eastern historian Procopius of Caesarea writes that "though he did not claim the right to assume either the garb or the name of an emperor of the Romans, [...] he invested himself with all the qualities that are appropriate to one who is an emperor by nature"13. The subject of Theoderic's imitatio Imperii has been investigated frequently during the last few years, ${ }^{14}$ but scholars have generally taken little notice of two embassies from the Warni and Hesti. When investigating the relations with distant peoples, they usually emphasize the military or strategic aims of Theoderic, ignoring the symbolic value of embassies received from far-away lands. However, these should be addressed in order to understand the real purpose of Theoderic's diplomacy with Northern Europe.

We may start by citing a diplomatic letter of Theodahad, Theoderic's nephew, which he sent to Justinian shortly after his accession to the throne of Ravenna. In it Theodahad wrote that:

Commune est cunctis in suis imperiis praedicari, sed illud est omnimodis singulare in extranea gente laudes proprias invenire, quia ibi sunt vera iudicia ubi neminem comprimit ulla timiditas. Diligeris quidem, piissime imperator, in propriis regnis: sed quanto praestantius est ut in Italiae partibus plus ameris, unde nomen Romanum per orbem terrarum constat esse diffusum $!^{15}$

"It is a common thing for all rulers to be praised in their own land, but to receive the praise of foreign peoples, that is indeed extraordinary, since you can find honest judgments where fear does not subdue anyone. You are loved, most pious emperor, in your own dominions;

12 See above all Giardina 2006; La Rocca - Oppedisano 2016.

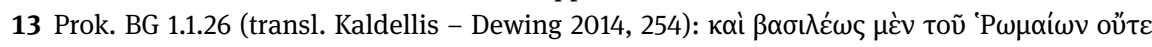

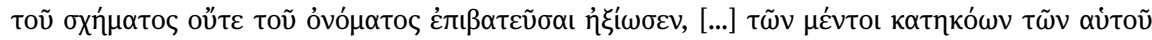

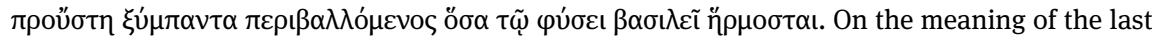
occurrence of basileus, see Wiemer 2018, 49: “Der Historiograph spielt hier mit der Vieldeutigkeit des griechischen Wortes basileus, das sowohl den römischen Kaiser als auch jeden anderen Alleinherrscher bezeichnen kann, der als legitim anerkannt wird.” However, an allusion to the (East) Roman emperor is likely, since he is openly mentioned just a few words earlier.

14 See especially Arnold 2014.

15 Cassiod. var. 10.19.3. 
but how much grander a thing to be yet more loved in the regions of Italy, from whence the Roman name was diffused over the whole world."16

This passage offers a good summary of Ostrogothic political ideology applied to foreign relations, focusing in particular on the praise of foreigners. Such praise often functioned as tangible proof of a ruler's excellence, since it reflected popular sincerity and not convenience.

Building upon five centuries of imperial ideology, Theodahad - and before him Theoderic - developed a conception of diplomatic space with far-reaching implications. ${ }^{17}$ If the respect of foreign peoples was a mark of greatness, the distance between a ruler and his correspondents stood in direct proportion to his fame. ${ }^{18}$ Moreover, Italy had been the cradle of the nomen Romanum, and so a ruler who desired to be worthy of such a glorious past had to spread the fame of Rome among far-away nations. For the Ostrogothic kings, diplomatic space was not static but highly dynamic, since it enabled multi-directional movement that potentially encompassed the whole known world: the fame of a sovereign spread to all lands, reaching even the most remote peoples, whose praise, together with precious gifts, was conveyed back to him through embassies. ${ }^{19}$ This strategy of political communication and its illustrious precedents can be reconstructed with regard to Theoderic's relations with two Northern peoples, as the following pages will try to illustrate.

\section{The Warni (Variae 5.1): Swords and Digressions in the Far North}

At the beginning of the fifth book of his Variae, a collection of 468 letters written on behalf of the Ostrogothic sovereigns from 507 to 538, Cassiodorus transcribed two diplomatic epistles. ${ }^{20}$ The first is addressed to the king of the Warni, a Ger-

16 Transl. Hodgkin 1886, 431, modified. Another translation of this passage can be found in Bjornlie 2019, 408.

17 On the notion of space in late antique historical works, see Van Nuffelen 2019 (ed.), especially his introduction: "We understand space here in the sense of geographical space mediated through narrative" (ibid. 3).

18 There was a sincere interest in geography at Theoderic's court in Ravenna, see Staab 1976.

19 See for instance Ennod. pan. 89: Quaecumque ornamenta mundo obsequente transmissa fuerint, decorata venerandi genio corporis plus lucebunt.

20 For a recent translation and a detailed commentary of each epistle, see Giardina et al. 2014. Bjornlie 2013 argues that Cassiodorus engaged in a widespread revision of individual letters 
manic people living in Northern Germany, not far from the mouth of the Rhine. ${ }^{21}$ Theoderic thanked the legates of the Warni for their valuable presents, which consisted in "sable furs, slave boys who shine with the fair colour of barbarians and [...] swords, so sharp than they can cut even through armour"22 and so beautiful that they "might be thought the work of Vulcan" ${ }^{23}$. The rest of the letter is a quite lengthy digression on the swords, which the king concluded by expressing the hope that "Providence may grant concord" to both peoples. ${ }^{24}$

This letter is at first sight quite different from an ordinary diplomatic epistle, but the reader should not be deceived by its seemingly emptiness. Cassiodorus' rhetoric, once considered inflated and idle, is instead an important part of the political communication of Theoderic, ${ }^{25}$ who was depicted as a ruler keen to spread the name of Rome in a famous inscription of Terracina written by Cassiodorus himself. ${ }^{26}$ Scholars have often discarded Cassiodorus' digressions in order to concentrate on the historical facts reported by the Variae, but in doing so they have risked missing the main purpose of Theoderic's epistles, since digressions are an important part of them. ${ }^{27}$ Var. 5.1 is usually believed to concern an anti-Frankish alliance with the Warni, who lived near the Northern borders of the Franks, ${ }^{28}$ bitter enemies of the Ostrogoths after the battle of Vouille and the War of Provence. This explanation, however, is quite difficult to reconcile with both the letter itself and its historical context.

before circulating the Variae (in the 540s) and that he added many digressions, with the aim of demonstrating his suitability to return to a role in the government of Italy. However, this theory is far from convincing; see for instance the reviews by Wiemer 2013 and Heather 2016. As far as the main aim of the Variae is concerned, there is no reason why we should disregard what Cassiodorus himself wrote in the preface: rudes viros et ad rem publicam conscia facundia praeparatos labor tuus sine aliqua offensione poterit edocere (praef. 8, Cassiodorus' friends are speaking). See also Giardina 2006, $38 \mathrm{f}$.

21 Springer 2006. See also the commentary on this letter by La Rocca in Giardina et al. 2014, $403 \mathrm{f}$.

22 Cassiod. var. 5.1.1 (transl. Barnish 1992, 83, slightly modified): Cum piceis timbribus et pueros gentili candore relucentes, spathas nobis etiam arma desecantes vestra fraternitas destinavit, ferro magis quam auri pretio ditiores.

23 Cassiod. var. 5.1 .2 (transl. Barnish 1992, 83): pulchritudine sui putentur esse Vulcani. On these swords, see Davidson - Schulz 1961.

24 Cassiod. var. 5.1.3: Praestent divina concordiam.

25 See for example Giardina 2006; Giardina 2012; Devecka 2016. Mommsen 1894, XXII, used the concepts of exilitas and vaniloquentia in order to describe Cassiodorus' prose.

26 CIL 10.6850: Theoderic is called propagator Romani nominis. He is therefore a worthy ruler of Italy, the land unde nomen Romanum per orbem terrarum constat esse diffusum (Cassiod. var. 10.19.3).

27 On Cassiodorus' digressions, see Nickstadt 1921; more recently Pieroni 2011; Bjornlie 2015.

28 See for instance the commentary by La Rocca in Giardina et al. 2014, 403. 
Theoderic did use diplomacy to forge defensive alliances, as for example before the war in southern Gaul in 507. But on this occasion, he explicitly stated his purposes, warning a people not to attack his allies or urging another to fight alongside the Ostrogoths against a common enemy. ${ }^{29}$ The letter to the Warni contains neither direct nor oblique warnings, apart from the mention of concordia, which is a common motif of Theoderic's political communication. ${ }^{30}$ Moreover, it begins with a description of the gifts brought by the Warni, whereas the first four epistles of book three, which were written in order to avoid a war with the Franks, never mention presents of any kind and begin directly by dealing with the main question of alliance.

Here it should be added that this epistle was written between 523 and 526, as all editors agree, ${ }^{31}$ and Cassiodorus decided to put it at the beginning of his fifth book, in a very important position. By the end of Theoderic's rule, the enemies of the Ostrogoths were no longer the Franks, but the Vandals, who had arrested and executed Theoderic's sister, and the Burgundians, whose king had killed his son, Theoderic's grandson; because of this murder they came under attack by the (nominally) allied Ostrogothic and Frankish armies. ${ }^{32}$ Theoderic would have had no reason to jeopardize his relationship with the Franks, who had become his most important allies, by strengthening his ties with the Warni.

Therefore, the letter does not appear to be chiefly aimed at forming an anti-Frankish alliance. It was also not sent merely for the sake of politeness, as is revealed by its learned digression and - more importantly - by its prominent position in Cassiodorus' collection, where the first letter of each book always refers to important circumstances. To mention only the epistles written in the name of Theoderic, Var. 1.1 and 2.1 were sent to the emperor Anastasius in order to restore mutual confidence with Constantinople after years of tense relations; Var. 3.1 to Alaric II, king of the Visigoths, in order to avoid the outbreak of the War of Provence; and Var. 4.1 to Herminafred, king of the Thuringians, shortly before his marriage with Amalaberga, Theoderic's niece. Var. 5.1 is hence relevant not only because it is the first epistle of book five, but also because it is the first letter

29 Respectively Cassiod. var. 3.2.4, and Cassiod. var. 3.1.3.

30 See Cristini 2019a.

31 Mommsen 1894, XXIX, and 143; Fridh 1973, 182; Giardina et al. 2014, 137, with the commentary of A. La Rocca (ibid., 403). Bjornlie 2013, 178, argues that "the first and last two letters of Book 5 originated from Cassiodorus' quaestorship (507-511), not his mastership of the office”, but his only argument seems to be a comparison with Cassiod. var. 3.3. Since Cassiod. var. 5.1 bears witness to a much stronger relationship with the Warni than in Cassiod. var. 3.3, which was jointly addressed to three different peoples, it is likely that Cassiod. var. 3.3 precedes Cassiod. var. 5.1. 32 On these events, see Steinacher 2016, 288-292, and Favrod 1997, 428-449. 
of the last book containing Theoderic's correspondence. Cassiodorus arranged his letters very carefully and for this reason he could have intended to establish a parallel between Var. 1.1, which includes the famous expression regnum nostrum imitatio vestra est ("our kingdom is an imitation of you [that is, the emperor]"), and Var. 5.1. In order to clarify this assumption, however, it is necessary to analyse the next epistle.

\section{The Hesti (Variae 5.2): Amber, Tacitus and imitatio Augusti}

Variae 5.2 is a letter written in $523-526,{ }^{33}$ which is around the same time as the epistle to the Warni. It was sent to the Hesti, a people who dwelt in Oceani litoribus ("on the coast of Ocean"), that is, on the coast of the Baltic Sea. ${ }^{34}$ They had previously sent some amber to Theoderic, who thanked them and described the origins of amber. This text has often been used in order to investigate ancient amber routes ${ }^{35}$, the trade between Italy and the Baltic ${ }^{36}$ or the knowledge of Latin and Greek authors about amber ${ }^{37}$, but in doing so scholars have overlooked the symbolic value of this document.

The context is similar to that of the first epistle. Theoderic was not seeking a military alliance with the far-away Hesti, nor was he interested in defending his people or allies from possible aggression by this remote nation. Nevertheless, Cassiodorus not only transcribed the letter in his Variae, but he also placed it at the beginning of book five, immediately after the letter to the Warni, and adorned it with a learned digression about amber ${ }^{38}$. This again seems a redundant display of learning if the king only wanted to thank the Hesti.

The key to understanding the importance given by Cassiodorus to this epistle is hidden in its first words. Theoderic writes: grande vos studium notitiae nostrae habuisse cognovimus [...] suavis nobis admodum et grata petitio ut ad vos perveni-

33 Tanzi 1887, 36, writes that this letter cannot be dated, but Mommsen 1894, XXIX, conjectures that almost all letters of book five were written between 523 and 526. Fridh's and Giardina's editions share the same belief, as does Spekke 1939, 311.

34 Cassiod. var. 5.2.1. On the Hesti, see Spekke 1939; Saks 1960; Schmid 1973. On this epistle and its ideological aims, see Cristini 2018.

35 Spekke 1976, 94-97. See also Saks 1960, 25-32.

36 Kolendo 1993.

37 Kolendo 1993, 54-66; Aricò 1986, 168; Gasti 2001, 142.

38 On amber during Classical Antiquity, see Sallmann 1998. 
ret fama nostra ("we learned that you have a great desire to know us. [...] It is gratifying to us to know that you have heard of our fame") $)^{39}$. Theoderic is glad that his fame has reached the shores of the Baltic Sea and quotes Tacitus (referring to him indirectly as "a certain Cornelius"40), who had briefly dealt with the Hesti at the end of his Germania, writing that they lived on "another sea, sluggish and almost motionless, with which the earth is girdled and bounded. [...] So far (and here rumor speaks the truth), and so far only, does the world reach"41. The Hesti lived at the end of the known world, so to speak, so Theoderic's fame had reached the boundaries of inhabited lands.

Roman emperors were proud of receiving embassies from remote countries, especially Augustus, who welcomed legates that came from India and Scythia. The mention of India is crucial, because this country was connected with the myth of Alexander and symbolized the Eastern frontier of the known world. ${ }^{42}$ The Res gestae divi Augusti states that ad me ex India regum legationes saepe missae sunt non visae ante id tempus apud quemquam Romanorum ducem ("ambassadors from the Indian kings were often sent to me, which had not been seen before by any Roman leader") ${ }^{43}$.

Now, Theoderic welcomed an embassy of Hesti, Augustus one of Indians, but both were glad that their fame had reached the frontiers of the known world and both expressed their pride in official documents. Allusions which tacitly compared Theoderic and Augustus, who began his Res gestae by stating that he subjected the whole world to the rule of the Roman people, ${ }^{44}$ were often implicit in

39 Cassiod. var. 5.2.1 (transl. Hodgkin 1886, 265).

40 Cassiod. var. 5.2.2: quodam Cornelio describente.

41 Tac. Germ. 45.1 (transl. Hutton - Peterson 1970, 207): Aliud mare, pigrum ac prope immotum, quo cingi claudique terrarum orbem [...]. Illuc usque - et fama vera - tantum natura. For a brief commentary, see Rives 1999, 317, where, however, Theoderic is erroneously referred to as a "Visigothic king”. See also Anzinger 2015, 348-350.

42 On India as the 'end of the world', see e.g. Curt. 9.6.20: While fighting in India, Alexander says to his soldiers that iamque haud procul absum fine mundi. Similar words were uttered shortly before, see Curt. 9.3.8: Paene in ultimo mundi fine consistimus. Such an image of the world was not rare in Late Antiquity, see e.g. Claud. 4 cons. Hon. 257: Tu licet extremos late dominere per Indos; Alc. Avit. carm. 1.211-212: Ergo ubi transmissis mundi caput incipit Indis, / quo perhibent terram confinia iungere caelo. On Alexander's myth during Late Antiquity, see below, note 54 .

43 R. Gest. div. Aug. 31. On Augustus and his imitatio Alexandri, see Nenci 1958 and Kienast 1969; more recently, Braccesi 2006, especially 117-141; O’Sullivan 2016; Wallace 2018.

44 R. Gest. div. Aug. praef.: orbem terrarum imperio populi Romani subiecit. On Augustus universal aspirations, see Mehl 1994. See also Ando 2000, 320-329, who offers a brief survey of the concepts of orbis and world dominion during the Early Empire. For a more detailed study, see Mastino 1986, 70-73. On the sixth century, see Suerbaum 1961, 266 f. 
Ostrogothic political communication, ${ }^{45}$ so it will be worthwhile to look further into Theoderic's use of Augustan ideology.

\section{Fame Without End: the Indian Embassy to Augustus and Cassiodorus' Letter to the Hesti}

It is impossible to determine whether Cassiodorus ever read the Res gestae or not, ${ }^{46}$ but he doubtless knew other sources about Augustus, such as Suetonius, Eutropius and Orosius, whose accounts of the Indian embassy to Augustus share a few significant elements with Cassiodorus' letter to the Hesti. ${ }^{47}$ Suetonius already praised Augustus' virtue and moderation, and mentioned that his fame had reached the Indians. Theoderic's fame, likewise, was known even to the remote Hesti. ${ }^{48}$

More importantly, both Indians and Scythians, who did not know the Roman name before Augustus, sent him gifts and ambassadors according to Eutropius. Spreading the nomen Romanum was one of the cornerstones of the ideology of Theoderic, ${ }^{49}$ as is shown by his epithet propagator Romani nominis ("he who propagates the Roman name") ${ }^{50}$. Eutropius writes that the name of the Romans was unknown (incognitum) to Indians and Scythians and Theoderic exhorts the Hesti to love him cognitus, that is, once they came to know him who previously was ignotus (i.e. unknown to them). ${ }^{51}$ Cassiodorus knew Eutropius well, for he

45 See Arnold 2014, 90 f., and below, paragraph five. See also Deliyannis 2010, 382, who points out the similarities between Theoderic's and Augustus' mausoleum.

46 Nothing is known about the conditions of the Mausoleum of Augustus during Late Antiquity and the early Middle Ages, see von Hesberg - Panciera 1994, 66-68. However, Rome played a quite important role in Theoderic's ideology (see for instance Arnold 2017) and the king remained there for six months in 500 (Exc. Val. 65-70), so it is not impossible that he admired Augustus' mausoleum and its inscriptions.

47 On the Indian embassy, see Biffi 2004; more recently, Albaladejo Vivero 2018.

48 Suet. Aug. 21.3: Qua virtutis moderationisque fama Indos etiam ac Scythas auditu modo cognitos pellexit ad amicitiam suam populique Romani ultro per legatos petendam. Cf. Cassiod. var. 5.2.1: [...] ad vos perveniret fama nostra. See also Ennod. pan. 9: Non tibi ignotus est algor Scythiae, non Meroen aut anhelum aestibus Cancrum ut alterius possessor orbis ignoras: didicisti universa subgiendo quae nobis vix auditu patuerunt.

49 Moorhead 1987.

50 CIL 10.6850. See above, note 26.

51 Eutr. 7.10: Scythae et Indi, quibus antea Romanorum nomen incognitum fuerat, munera et legatos ad eum miserunt. Cf. Cassiod. var. 5.2.1: Amate iam cognitum, quem requisistis ambienter ignotum. Cassiodorus could also have read Vell. 2.60.1: Adserebant salutaria rei publicae 
used him as a source extensively in his Chronicle, so on that basis we might surmise that he intentionally alluded to a passage of his predecessor in order to point out the analogies between Augustus and Theoderic.

Finally, Orosius wrote that the ambassadors of Scythians and Indians found Augustus in Hispania, "in the furthest land of the West", "after crossing the whole world" in order to bring him presents. ${ }^{52}$ The gifts of Scythians and Indians hence stood as tangible proof that Augustus had won worldwide fame, just as the gifts of Warni and Hesti represented that Theoderic's fame was boundless.

Of course, any of these analogies, if examined individually, could be considered a mere coincidence of similar outlooks, but they show meaningful similarities with the accounts of the Indian embassy if they are analysed together. These parallels are also able to be confirmed in another source. According to Jordanes, the Gothic king Ermanaric also defeated - among other peoples - the Hesti ${ }^{53}$ and achieved such glory that merito nonnulli Alexandro Magno conparavere maiores ("some of our ancestors have justly compared him to Alexander the Great") 54 . Like his illustrious predecessor, who reached the edges of the Earth to conquer India, Ermanaric reached the frontiers of the known world to subdue the Hesti. Jordanes' work is a revised epitome of Cassiodorus' lost "Gothic History", so it seems highly likely that the mention of Ermanaric's deeds comes directly from the pen of the minister of the Ostrogothic kings. ${ }^{55}$

terrarumque orbis fata [Augustum] conditorem conservatoremque Romani nominis. See also Tac. Agr. 23: Quarta aestas obtinendis quae percucurrerat insumpta; ac si virtus exercituum et Romani nominis gloria pateretur, inventus in ipsa Britannia terminus. The "glory of the Roman name" occurs together with the idea of reaching the frontier of Britain, i.e. the frontier of the known world. Cassiodorus quotes Tacitus' Germania in Cassiod. var. 5.2 and Jordanes, while summarizing Cassiodorus' "Gothic History”, quotes Tacitus' Argicola (see Iord. Get. 13 and Tac. Agr. 12), so it is possible that this passage was also taken into consideration when writing Var. 5.1-2.

52 Oros. Hist. 6.21.19-20: Interea Caesarem apud Tarraconem citerioris Hispaniae urbem legati Indorum et Scytharum toto orbe transmisso tandem ibi invenerunt, ultra quod iam quaerere non possent, refuderuntque in Caesarem Alexandri Magni gloriam: quem sicut Hispanorum Gallorumque legatio in medio oriente apud Babylonam contemplatione pacis adiit, ita hunc apud Hispaniam in occidentis ultimo supplex cum gentilicio munere eous Indus et Scytha boreus oravit. There is a clear idea of universal power in this passage, as emphasized by the use of orbis, which occurs also in Tacitus' description of the Hesti (see above). For other comparanda, see Cristini 2018.

53 Iord. Get. 120: Aestorum quoque similiter nationem, qui longissimam ripam oceani Germanici insident, idem ipse prudentia et virtute subegit.

54 Iord. Get. 116 (transl. Mierow 1915, 84). The popularity of Alexander's myth during Late Antiquity is attested by the so-called Alexander Romance, a Greek fictional account of the deeds of Alexander which was widely copied and translated. On the legacy of Alexander during Late Antiquity, see Peltonen 2019, especially 138-141.

55 On the relationship between Jordanes and Cassiodorus, see most recently Van Hoof - Van Nuffelen 2017. 
Jordanes (and possibly Cassiodorus) compared Ermanaric with Alexander, since both subjugated remote peoples, and could have drawn a comparison between Theoderic and Ermanaric, who were both great Gothic kings who had contacts with the far-away Hesti. ${ }^{56}$ It would have been tempting to relate Theoderic directly to Alexander, as Ennodius had done in his Panegyric ${ }^{57}$, but this parallel was unsuitable, because Alexander had conquered India, just as Ermanaric had allegedly subjugated the Hesti, whereas Theoderic never subdued this Northern people. He only welcomed their envoys, after his fame reached lands where his soldiers were hitherto unknown. Therefore, Cassiodorus did not try any imitatio Alexandri. Instead, he decided to allude to a ruler who, like Theoderic, did not reach the frontiers of the world with his army, but only with his fame, which enabled him to receive envoys from distant countries. This ruler was Augustus.

\section{Virgil Among the Warni}

As we have seen, it was unusual for Cassiodorus to begin a document that is ostensibly aimed at a military alliance with the mention of exotic gifts sent to him by other Germanic peoples. Of course, gifts are present in other diplomatic epistles, namely Var. 1.46 and 2.41, which were sent respectively to Gundobad, king of the Burgundians, and Clovis, king of the Franks, shortly before the outbreak of the War of Provence. However, both letters describe gifts sent by the Ostrogothic king to other rulers, not received by him from them. Var. 5.1-2 are the only epistles which dwell on diplomatic gifts brought to Ravenna by foreign ambassadors. ${ }^{58}$

Since it has been shown that the epistle to the Hesti possibly contains a few allusions to the Indian embassy to Augustus, it is necessary to turn our attention to the description of the diplomatic gifts sent by the king of the Warni. Cassiodorus' mention of the god Vulcan and the prospect of concord in Var. 5.1 recalls

56 See Wolfram 1989. Jordanes described Ermanarich "als eine Art Präfiguration Theoderichs des Großen”.

57 Ennod. pan. 79-80. See Rota 2001, 216.

58 The auri munera sent by Thrasamund to Theoderic (Cassiod. var. 5.44) should not be considered - strictly speaking - a diplomatic gift, since they were more a compensation which the Vandal king offered to the Ostrogoths in the hope that Theoderic would forgive his support of Gesalic, a pretender to the Visigothic throne who had tried to overthrow Theoderic's nephew Amalaric. The gifts sent by Herminafred (Cassiod. var. 4.1) are part of the so-called 'Kaufehe', a Germanic custom according to which the family of the bride should receive gifts from the would-be husband in order to compensate for the loss of a member of the household. See the commentary on this letter by F. E. Consolino, in Giardina et al. 2014, 312. 
a few verses of Virgil, who wrote an ekphrastic description of Aeneas' shield in the eighth book of his Aeneid. Here, Virgil provides the reader with a brief summary of Roman history, which includes a description of the battle of Actium:

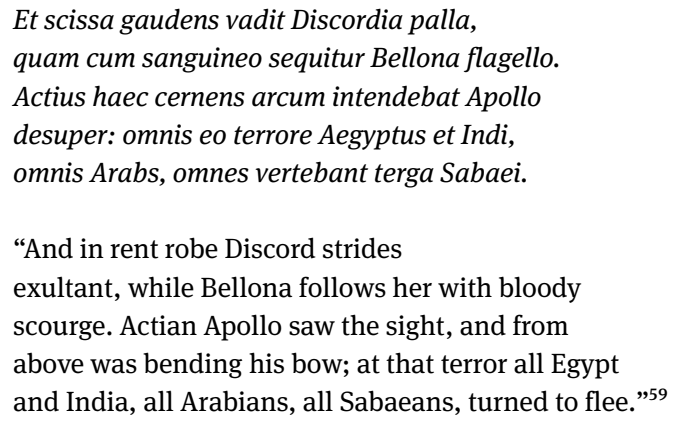

In these famous verses, we find the personification of Discord and the Indians on a shield made by Vulcan, the same god who, according to Cassiodorus, is said to have forged the swords which the Warni brought to Theoderic. The god Vulcan is mentioned only once in the Variae, in the above-mentioned passage ${ }^{60}$; moreover, Cassiodorus writes that Vulcan "fashioned implements (fabrilia) of such grace that men believed the work of his hands to be not mortal, but divine"61. Virgil describes Vulcan preparing to forge Aeneas' weapons as follows: "the Lord of Fire rises from his soft couch to the work of his smithy (fabrilia)" ${ }^{62}$ There is only one occurrence of the substantive fabrilia in both the Variae and Virgil's works, which suggests that this is a quite meaningful analogy. In addition, the inverse of discordia, concordia, is referred to in Var. 5.1 and the next epistle, that to the Hesti, alludes to Augustus and the Indian legates ${ }^{63}$. Of course, the Indians did not take part in the battle of Actium, but Virgil mentioned them nevertheless, perhaps after their embassy reached the emperor, in order to stress his dream of world conquest. ${ }^{64}$

59 Verg. Aen. 8.702-706 (transl. Rushton Fairclough, II, 109).

60 Cassiod. var. 3.47 refers to the island of Vulcano, in the archipelago of the Aeolian Islands.

61 Cassiod. var. 5.1.2 (transl. Barnish 1992, 83).

62 Verg. Aen. 8.415 (transl. Rushton Fairclough, II, 89): mollibus e stratis opera ad fabrilia surgit. 63 Since defensive weapons have become offensive and discord becomes concord, we are seemingly faced with a kind of inversion, which could be explained by the fact that Theoderic was ultimately - superior to Augustus according to sixth century political communication (see below, section seven). However, it is more likely that this 'inversion' was a mere consequence of the presents brought by the Warnian envoys (swords, not shields) and Theoderic's ideology (which was focused on concord, not on discord).

64 See Fratantuono - Smith 2018, 723. 
Cassiodorus, like all late antique Roman aristocrats, knew the Aeneid very well, so it is no surprise that he alluded to it in a bid to establish a parallel between Augustus and Theoderic, who shared the same ideological project, since both desired to spread their fame throughout the world. ${ }^{65}$

\section{The Representation of Augustus in the Variae}

In order to better understand Theoderic's imitatio Augusti, there are two other passages of equal historical importance. Firstly, Var. 3.51 is a letter to Faustus Niger, praefectus praetorio between 507/509 and 512, ${ }^{66}$ about the monthly allowance given to a famous charioteer called Thomas. Cassiodorus deals with this topic in a few lines and then makes a learned digression about the Circus Maximus, reporting that mundi dominus ad potentiam suam opus extollens mirandam etiam Romanis fabricam in vallem Murciam tetendit Augustus ("Augustus, the lord of the world, raised a work equal to his power, and laid out a construction in the Murcian valley that is a marvel even to the Romans") ${ }^{67}$. Theoderic was famous for his building activity (the Excerpta Valesiana calls him amator fabricarum et restaurator civitatum - "lover of buildings and restorer of cities") ${ }^{68}$, and it is hardly surprising that Cassiodorus allusively compared him to Augustus, a ruler who used to say that he "had found Rome built of brick and left it in marble" ${ }^{69}$. Interestingly, the first Roman emperor is called mundi dominus, lord of the world, an expression emphasizing his universal power.

The following letter, Var. 3.52, deals with a dispute between two landowners called Leontius and Paschasius, who were in a quarrel over the boundaries of

65 Other Roman emperors also shared this ideology (see Mastino 1986, 108-111, dealing with Constantine, and Koehn 2018, 146-166, dealing with Justinian), but Theoderic stressed the importance of diplomacy with remote peoples using expressions reminiscent of Augustan ideology, so these letters were aimed not at a vague imitatio Imperii, but at an imitation of a specific emperor, Augustus. On Cassiodorus and Virgil, see Minicucci 1983, with the comments of Viscido 1991, and Polara 1984. Another common motif of the ideologies of Augustus and Theoderic was the praise of concord, see Lobur 2008 and Cristini 2019a.

66 See PLRE 2, 454-456 (Faustus 9); PChBE 2, 756-759 (Faustus 4); cf. also the commentary on this letter by Cracco Ruggini, in Giardina et al. 2014, 294.

67 Cassiod. var. 3.51.4 (transl. Barnish 1992, 68).

68 Exc. Val. 70. See Johnson 1988; La Rocca 2014.

69 Suet. Aug. 28.3: Urbem [...] marmoream se relinquere, quam latericiam accepisset. The English translation is taken from Rolfe 1979, 167. 
their properties. ${ }^{70}$ After a digression about geometry and land-surveying, Cassiodorus writes: Augusti siquidem temporibus orbis Romanus agris divisus censuque descriptus est ("For, in the time of Augustus, the Roman world was divided into fields, and registered by census") ${ }^{71}$. Theoderic promoted a fair process of tax collection ${ }^{72}$, and an implicit comparison with the first Roman emperor was doubtless flattering. Moreover, Augustus is mentioned for the second time in close connection with the world, which this time is not designated by mundus but by orbis, and is accompanied by the adjective Romanus. ${ }^{73}$

The only two mentions of emperor Augustus in the Variae, which occur in two neighbouring epistles, show that Cassiodorus also aimed to stress the similarities between Theoderic and the heir of Caesar (as well as the universal power of the latter) in letters that were not concerned with foreign relations, since these analogies, and Theoderic's universal aspirations more generally, belonged to the strategy of political communication used in the Ostrogothic court. His imitatio Augusti rested upon the common rhetorical trope of mundi dominatio, as well as upon the common interest for Rome and the well-being of its inhabitants. ${ }^{74}$ Theoderic and his successors were compared more than once with other emperors such as Trajan and Valentinian, and therefore an analogy with Augustus is hardly surprising. ${ }^{75}$

\section{The Intended Audience of Variae 5.1-2}

Mention of learned digressions and allusions brings us to a subject that can no longer be postponed, namely the audience of Var. 5.1-2, as well as that of the diplomatic letters included in the Variae. The Warni and the Hesti would probably not have caught the classical references and the meaningful allusions of Var. 5.1-2, which could therefore seem aimless at first sight. However, diplomatic

70 See PLRE 2, 672 (Leontius 22); PLRE 2, 835 (Paschasius 2); cf. also the commentary by Porena in Giardina et al. 2014, 298-303.

71 Cassiod. var. 3.52.6 (transl. Barnish 1992: 72). See also Brodersen 2003, 261-267.

72 See e.g. Cassiod. var. 2.24 and 4.14. On taxes in Ostrogothic Italy, still valid is Soraci 1974, 83-137; see also Bjornlie 2014, 145-158.

73 The idea of world dominion was often expressed by the word orbis in the age of Augustus; see Vogt 1960: 159-161.

74 The imitation of Augustus was not uncommon during Late Antiquity, as is indicated e.g. by the political communication of emperor Constantine, see Vera 2016.

75 Trajan: Exc. Val. 60, 71; Cassiod. var. 8.3.5, 8.13.4-5. Valentinian: Exc. Val. 60. On Trajan as a model ruler in Late Antiquity, see Vitiello 2015, 35-39. 
letters were probably read aloud in front of the foreign ambassadors and the main Roman officials of Ravenna's court. ${ }^{76}$ They were likely also circulated in order to strengthen the quasi-imperial image of Theoderic among his subjects and neighbouring sovereigns, as a letter from king Sigismund to emperor Anastasius might suggest. In this text the Burgundian ruler complained that Theodoric had prevented an embassy headed for Constantinople from crossing his territories, although the Ostrogothic king de pace vestra publice plauderet et rumore disperso redditam sibi Orientis gratiam coloraret ("was publicly applauding your peace and, once the false rumor had been dispersed, was pretending that the favour of the East had been given back to him") ${ }^{77}$. Peace (pax) is one of the keywords of Var. 1.1, whereas favour (gratia) is mentioned in Var. 2.1, both of which were letters sent to Anastasius. It is therefore likely that Theoderic circulated these documents with the aim of showing that he was again on friendly terms with the Empire. ${ }^{78}$

The classical allusions of Var. 5.1-2 and the political ideology behind them would have been easily understandable to members of the senatorial aristocracy such as Liberius or Boethius. Theoderic desired to be considered by his subjects, and especially by the senators, as a worthy successor of the Roman emperors, and embassies from far lands were commonly used by late antique rulers in order to increase their prestige, as is shown for instance by Corippus' panegyric of Justin II. The arrival of an embassy of Avars is compared with the venationes of Hyrcanian tigers, and the envoys enter the palace amid thousands of people eager to look at them. ${ }^{79}$ Of course, here Corippus refers mainly to common people, but it is doubtless that there were also members of the court and senators present on such occasions. The reception of embassies was considered as a public event. ${ }^{80}$

Turning again to Italy, we know that foreign envoys took part in sumptuous banquets in the palace of Theoderic ${ }^{81}$ and quite a few members of Ravenna's court (e.g. the praetorian prefect, the magister officiorum, the comes patrimonii) dealt with them. Therefore, it is likely that the learned allusions of Var. 5.1-2 were above all aimed at Roman aristocrats such as Boethius (who was magister officiorum in 522-523) and his father-in-law Symmachus. Still, they can also be regarded as

76 Some diplomatic letters were written for an oral performance, see Gillett 2010, 152.

77 Avit. Vienn. Epist. 89.4 Malaspina = 94 Peiper (transl. Shanzer - Wood 2002, 151).

78 Gillett 2003, 182, comes to a similar conclusion regarding Cassiodorus' diplomatic epistles: "Like most ancient correspondence, the letters could be expected to be read publicly and possibly to circulate, thus serving as an introduction to discussions."

79 Coripp. Iust. 3.246-250.

80 See Becker 2018, 86.

81 See Cassiod. var. 6.9.7, 12.4.1. 
part of a strategy of political communication addressed to neighbouring peoples (e.g. the Burgundians) and the Empire.

\section{Senarius and Theoderic's Global Diplomacy}

So far the discussion has focussed exclusively on the Variae. Further light may be shed on the issue of Theoderic's universal aspirations by turning now to Senarius' epitaph. As we have seen, Theoderic, like Augustus before him, desired to give a universal dimension to his power, but, just like the first Roman emperor, he also had to deal with the geopolitical reality of the moment. Neither the heir of Caesar nor the Ostrogothic king had subjugated all neighbouring peoples, whereas their illustrious predecessors, namely Alexander the Great and the Roman emperors, had allegedly achieved this goal, so it was necessary to replace military victories with a careful strategy of political communication.

It is not known what the official aims of the embassies to Augustus and Theoderic were, but they were immediately used for ideological purposes, in order to show that the fame of the prince had reached the end of the world. Thus, a solution begins to emerge to the interpretative problems encountered when reading the letters to the Warni and Hesti. It is now time to return to the epitaph of Senarius and read its first fourteen verses.

Ille ego sum mundi quondam sine fine viator

Senarius, membris tumulo, non nomine, clausus,

Principis invicti semper sublimis amore,

Cuius in orbe fui vox regum, lingua salutis,

Foederis orator, pacis via, terminus irae,

Semen amicitiae, belli fuga, litibus hostis.

Novit et hoc Oriens, hoc ultimus axis Iberi;

Hoc scit bruma rigens, scit et Africa solibus usta.

Bis denas et quinque simul legatio nostra

Signat in orbe vias et numquam strata labore.

Cursus erat volucer, namque anno pervigil uno

Bis maris Oceani, bis Pontica litora vidi,

Europamque Asiamque sequens, duo limina mundi.

"I am that former, ceaseless wayfarer of the world,

Senarius, my limbs, but not my name, imprisoned by the tomb,

forever distinguished by the love of my unvanquished prince.

Of whom in the world I was the voice of kings, the language of security,

the orator of alliance, the path of peace, the boundary of wrath,

the seed of friendship, the banishment of war, the foe of strife. 
This the East also knows, this the furthest sky of Spain, this the dumb North knows, this knows the sun-scorched Africa.

Twice ten and five times our embassy

marked its paths upon the world and was never overcome by fatigue.

My passage was fleet, for, ever-watchful, in one year

twice I saw the shores of the Ocean, twice those of Pontus,

the two limits of the world, traversing both Europe and Asia. ${ }^{82}$

In this text, Senarius calls himself a traveller of the world and the voice of Theoderic (his princeps) over the whole globe. It should be noted that there are two occurrences of 'world' (mundus and orbis) in the first four verses, then another in verse ten. Both East and West, North and South - in short, the whole globe bear witness to Senarius' indefatigable activity. This sort of late antique Ballad of East and West offers significant indirect insights into the aims of the Amal king, which are faithfully mirrored in the funerary inscription, possibly because Senarius had long worked at Ravenna and he, like Cassiodorus, had helped to shape the Ostrogothic political communication. It would be pointless to wonder about his sincerity, since it is likely that the inscription was located in a public space (perhaps a cemetery near Ravenna) and the memory of the diplomatic activity carried out on behalf of Theoderic would have been highly flattering for both the deceased and his heirs.

Theoderic's diplomacy, like his fame, was supposed to encompass the whole world and in this light he could claim to be a legitimate heir of the Roman emperors. ${ }^{83}$ The surviving sources enable us to recognize his policy of imitatio Imperii only as far as the Northern peoples of Var. 5.1-2 are concerned, who live where the bruma, literally the winter solstice, is ice-cold, but it is likely that Cassiodorus deployed the same rhetorical skills for peoples from other remote regions. ${ }^{84}$ It

82 Translation from Gillett 2003, 195, slightly modified (v. 4: Gillett prefers: "In the world I was his voice of kings”; v. 7: I prefer 'sky' instead of 'clime'; v. 10: Gillett translates the final words as "and never failed in its task"; v. 13: Gillett prefers "traversing both Europe and Asia, the two limits of the world").

83 Cf. Iord. Rom. 255: Sic quoque Augustus Caesar Octavianus, quo nullus imperatorum in bellis felicior nec pace moderatior fuit, civilissimus in omnibus. Qui ab oriente in occidente, a septentrione in meridie ac per totum oceani circulum cunctis gentibus una pace conpositis Iani portas ipse tunc clausit.

84 On the Northern 'edges of the Earth' during the Early Empire, see Romm 1992, 140-149. Augustus often referred to the Ocean in order to express his world dominion; see for instance Mehl 1994, 452f. Allusions to the 'edges of the Earth' were not uncommon in late antique historiography, see Van Nuffelen 2019, 54: "The margins of the world are a remarkable presence in latefifth- and sixth-century historiography [...]. The margins seem remarkably well known in late antiquity and appear intimately connected to the empire.” 
should be added that the 'remoteness' of the Warni and Hesti is well attested by other sixth century authors, namely Procopius of Caesarea and Jordanes. ${ }^{85}$

Bruma rigens is also a classical quotation, from the beginning of Lucan's Pharsalia. There, Lucan writes that, if the Romans had not fought each other during the Civil Wars, they could have subjugated the whole world. ${ }^{86}$ This quotation suggests that Theoderic's 'universal' ideology lies at the centre of the epitaph, where there is an explicit allusion to a passage about the Civil Wars, which were hinted at in Cassiodorus' epistle to the Warni, as we have seen. Senarius could be suggesting that the Ostrogothic king, his princeps, is superior to Caesar (and Augustus) in some respects, since he really reached, albeit only through his envoys, the Nordic bruma rigens. Cassiodorus might have added that Theoderic is superior to Augustus because discordia never strode exultant during his kingdom, which was based upon concord, as both Var. 5.1 and 5.2 indicate. Augustus had to fight Antonius in order to (symbolically) subjugate the Indians, whereas Theoderic was able to subjugate (again, symbolically) the Warni and Hesti without bloodshed, thanks to his fame and diplomacy.

We should, however, not forget the following verses of Senarius. Apart from another mention of orbis, he writes that he touched the shores of the Ocean and the Black Sea. The Hesti - it should be remembered - lived on the coasts of Ocean. ${ }^{87}$ Then, in the next verse, Senarius claims that he reached the two limits of the world. ${ }^{88}$ This was exactly what Theoderic (through Cassiodorus' letters) was eager to express. ${ }^{89}$ His ambassadors, like his fame, did reach the frontier of the known world, so it is not surprising that Cassiodorus put the letters to both the Warni and the Hesti at the beginning of the fifth book of the Variae. In this position they equalled in importance the letters sent to the kings of Franks,

85 See Prok. BG 4.20 and Iord. Get. 36, 120. See also Van Nuffelen 2019, 49-51.

86 Lucan. 1.13-18: Heu, quantum terrae potuit pelagique parari / hoc quem civiles hauserunt sanguine dextrae, / unde venit Titan, et nox ubi sidera condit, / quaque dies medius flagrantibus aestuat horis / et qua bruma rigens ac nescia uere remitti / astringit Scythico glacialem frigore pontum!

87 Cassiod. var. 5.2.1: in Oceani litoribus constituti. The Warni also lived on the shores of the Northern Ocean, according to Prok. BG 4.20.2. Ocean was often considered as the mythical frontier of the world, see e.g. Iord. Get. 4 and Sarti 2017, 81.

88 Gillett 2003, 195, translates vv. 12-13 "twice I saw the shores of the Ocean, twice those of Pontus, traversing both Europe and Asia, the two limits of the world", thus correlating duo limina mundi with Europamque Asiamque. However, it is preferable to consider the shores of the Ocean and of the Black Sea (maris Oceani [...] Pontica litora) as the "two limits of the world", since Europe and Asia can hardly be regarded as limina mundi.

89 A similar ideology can be found in Ennod. pan. 9: Non tibi ignotus est algor Scythiae, non Meroen aut anhelum aestibus Cancrum ut alterius possessor orbis ignoras; didicisti universa subgiendo quae nobis vix auditu patuerunt. 
Vandals and Burgundians or to Constantinople, because they showed that Theoderic "invested himself with all the qualities that are appropriate to one who is an emperor by nature" 90 , to describe him in the words of Procopius, and that his kingdom had really become a "copy of the only Empire”, to quote again the first epistle of the Variae.

The (ideal) global nature of Theoderic's diplomacy is also attested by Var. 6.9, a letter concerning the appointment of the comes patrimonii, who had to supply the royal palace with sophisticated food and other delicacies when foreign ambassadors came to the court of Ravenna paene ex tota orbis parte ("almost from every corner of the world") ${ }^{91}$. By doing so, Theoderic's minister and - it is assumed - the king himself would have become propemodum in toto mundo celeberrimus ("very famous nearly throughout the globe") ${ }^{92}$. Again, foreign ambassadors were mentioned in close connection with the word 'world' (first orbis, then mundus) and were of paramount importance in the spread of Theoderic's fame all over the globe.

Cassiodorus and the epitaph of Senarius have shown that embassies coming from the Far North played a fundamental role in Ostrogothic political ideology, as attested by the global pretensions of Theoderic's fame and by his allusions to peoples living at the end of the world, who in spite of their remoteness were not unaware of the Ostrogoths. To sum up, Theoderic's political communication according to Var. 5.1-2 closely followed the model of Augustus, the first propagator Romani nominis, in order to stress the universality of the king's fame. ${ }^{93}$ It remains to be investigated if the Amal sovereign also imitated contemporary Roman emperors and imperial ideology.

\section{The Purposes of Theoderic's Claim to Universality}

Emperors were always pleased to receive gifts from far-away peoples, which were often recorded by historians and chroniclers, as a recent monograph by Ekaterina

90 Prok. BG 1.1.26 (transl. Kaldellis - Dewing 2014, 254).

91 Cassiod. var. 6.9.7.

92 Cassiod. var. 6.9.8.

93 On this kind of Roman imperial ideology, see Ando 2000, 19-48, and Noreña 2011, especially 300-324. Of course, it is possible (and even likely) that Theoderic never read the Res gestae, but the idea that the first Roman emperor had been mundi dominus was widespread in the sixth century; see, for instance, Cassiod. var. 3.51.4, cited above, and Iord. Rom. 255. 
Nechaeva demonstrates. ${ }^{94}$ For example, Anastasius, according to Marcellinus Comes, received an elephant and two giraffes from India. ${ }^{95}$ Unusual gifts from remote peoples substantiated the ecumenical aspirations of the Eastern Empire, which were an important part of the political ideology of New Rome.

A recent article by Anthony Kaldellis has convincingly indicated that East Roman emperors often laid claim to rule over the entire world or, at least, to occupy a pre-eminent position among the rulers of other countries. ${ }^{96}$ Their purpose was threefold. Firstly, the idea of universal power was useful to justify a future re-conquest of lands once ruled by, but no longer in the possession of, the Empire, as for example Justinian did in Africa and Italy. ${ }^{97}$ Secondly, it allowed the emperors to establish client rulers who were not imperial subjects, but who acknowledged - more or less willingly - the superior domination of the emperor, although they lived outside the Empire. A good example are the Burgundians, whose king Sigismund wrote to Anastasius that "my people are yours" 98 . Thirdly,

94 Nechaeva 2014. See also Becker 2018, 86: "The more exotic the envoys looked and the more magnificent their gifts were, the more awe-inspiring this ritual became and the more legitimate was imperial power."

95 Marc. Com. Chron. s.a. 496. It is now generally accepted that the animals were diplomatic gifts sent from the ruler of Axum (Ethiopia) or Himyar (South Arabia); see Nechaeva 2014, 198-202. If these hypothesis are correct, then the mistake of Marcellinus could be ascribed either to the confusion between the countries on the Red Sea and India, which is present in many ancient writers, or to a deliberate choice, aimed at comparing Anastasius (and, in general, sixth-century Roman emperors) with Augustus (and possibly also with Alexander the Great, see Proc. Gaz. Pan. 10). One should not forget that Marcellinus Comes worked at the court of Constantinople and was close to the emperor Justinian. See also Io. Mal. 18.73,106 and possibly Paul. Sil. ekphr. 230: Indian embassies with gifts came to Constantinople in 532 and 549/550.

96 Kaldellis 2017. See Cassiod. var. 1.1.2: the emperor is totius orbis salutare praesidium. See also Iord. Rom. 2, where Jordanes writes that he is going to explain quomodo Romana res publica coepit et tenuit totumque pene mundum subegit et hactenus vel imaginariae teneat, and Rom.6, where he begins his chronicle by stating that Romani, ut ait Iamblicus, armis et legibus exercentes orbem terrae suum fecerunt. The adverb imaginari $[a]$ e, which literally means 'in pretence' (cf. ThlL 7.1.402, 59-68), summarizes well both sixth century imperial ideology and the real balance of power. See also Cod. Theod. Nov. 7.3 (A.D. 440): Nos quidem semper singulis atque universis ea provisionum maiestate consulimus, qua res Romana paulatim ad totius orbis terrarum processit imperium. [...] Quis dubitat suis commodis veteres rei publicae commoda praeferentes mundi finibus fines imposuisse Romanos. For the concept of 'Roman space' in late antique geographers, see Molè 1986; in Justinian's laws, see Lanciotti 1986; more generally, see Talbert, 1990.

97 See also Greatrex 2007, 158. Cf. Nov. 30.11.2: spes habere bonas quis etiam reliquorum nobis detentionem annuet Deus, quam prisci Romani usque ad utriusque oceani fines tenentes sequentibus neglegentiis amiserunt.

98 Alc. Avit. Epist. 88.3 Malaspina = 93 Peiper: verster quidem est populus meus. See Schreibelreiter 1989; Harris 2003, 33; more recently, see the detailed analysis by Wood 2014. 
the claim of universal rule was a way to enhance the prestige of the emperor and his diplomacy, which was often more effective than threats or sabre-rattling in order to accomplish the aims of imperial foreign policy. ${ }^{99}$ Ecumenical rhetoric was, in the words of Kaldellis, "a successful investment of soft power"100.

It is worth noting that the situation was exactly the same for Theoderic. He too used his prestige and his universal claims to justify the re-conquest of lands once ruled by Rome. When the Ostrogoths had to fight the Franks in 508 during the War of Provence, their aim was, according to Cassiodorus, to give back the antiqua libertas ("the ancient freedom") to the inhabitants of Gaul. ${ }^{101}$ This rhetoric could be believed by senators and neighbouring kings only if Theoderic was perceived as similar to a Roman emperor. ${ }^{102}$ To achieve this goal, it was necessary to look like one and hence to emphasize his universal fame.

At the same time, Theoderic also tried to establish a belt of buffer states near to his borders (for example the kingdoms of the Heruli and Thuringians), behaving like the Eastern emperor, to whom all other rulers rightfully looked up with reverence, as Cassiodorus wrote. ${ }^{103}$ Again, other kingdoms could feel reverence for Theoderic only if they thought that he was superior to them and his political communication was aimed at this goal.

Finally, prestige was the most effective weapon of Theoderic, who claimed the inheritance of Rome, a city which, especially under Augustus, was said to have ruled over the whole world. The sovereign was well aware that his kingdom did not encompass the whole orbis terrarum, but his fame and his ambassadors had reached the two limits of the Earth.

\section{Conclusion}

Ostrogothic understanding of diplomacy and political communication was deeply influenced by the Roman imperial past and - at least in the fifth book of the Variae - by Augustan ideology. Theoderic's diplomatic relations with distant peoples should be considered not only as a kind of 'Realpolitik', but also as a

99 On East Roman diplomacy in general, see Obolensky 1961; Lounghis 1980; Blockley 1992.

100 Kaldellis 2017, 291.

101 Cassiod. var. 3.17.1. On the War of Provence, see Schwarcz 1993; Delaplace 2000. On Theoderic's ideology of freedom, see Moorhead 1987; Cristini 2019b.

102 See Arnold 2014, 262-294, as far as Gaul is concerned.

103 Cassiod. var. 1.1.2: quos ceteri dominantes iure suspiciunt. For a detailed commentary of this epistle, see Giardina 2006, 116-141. On the buffer states surrounding Theoderic's kingdom, see Wolfram 2009, 313-319. 
source of legitimization, because they indicated that the king was not different from a Roman emperor, since both had conquered the most remote lands through their fame. If the core of Augustan imperial ideology is expressed by a famous verse of Virgil, imperium sine fine dedi ("I have bestowed dominion without end") ${ }^{104}$, Theoderic's policy of imitatio Imperii can be summarized by another quotation of the Aeneid, coming from the same passage:

\author{
Nascetur pulchra Troianus origine Caesar, \\ imperium oceano, famam qui terminet astris. \\ "A Trojan Caesar shall be born from a noble line, \\ who shall limit his empire with ocean, his glory with the stars."105
}

These words refer to Augustus, but they could just as well be applied to Theoderic, whose authority extended over Italy and Spain and whose fame reached the limina mundi, the lands of the Warni and the Hesti, where, as Tacitus writes, the world ends.

Acknowledgements: This article is an expanded version of a paper read at the 2018 "Oxford University Byzantine Society International Conference” and at the 2018 "Roman History PhD Seminar” at Scuola Normale Superiore. Thanks go to the audiences on both occasions for their helpful feedback.

\title{
Bibliography
}

Albaladejo Vivero 2018: M. Albaladejo Vivero, El Imperio Romano y la India. Replanteamiento de las relaciones diplomáticas, ETF(hist) 31, 2018, 31-48.

Amory 1997: P. Amory, People and Identity in Ostrogothic Italy. 489-554, Cambridge 1997.

Ando 2000: C. Ando, Imperial Ideology and Provincial Loyalty in the Roman Empire, Berkeley 2000.

Anzinger 2015: S. Anzinger, Post oceanum nihil? Albinovanus Pedo und die Suche nach einer anderen Welt, RhM 158, 2015, 326-407.

Aricò 1986: G. Aricò, Cassiodoro e la cultura latina, in: S. Leanza (ed.), Atti della settimana di studi su Flavio Magno Aurelio Cassiodoro (Cosenza - Squillace 19-24 settembre 1983), Soveria Mannelli 1986, 154-178.

Arnold 2014: J. J. Arnold, Theoderic and the Roman Imperial Restoration, Cambridge 2014.

104 Verg. Aen. 1.279.

105 Verg. Aen. 1.286-287 (transl. Rushton Fairclough 1916, I, 261, modified). See also Mehl 1994, $436 \mathrm{f}$. 
Arnold et al. 2016: J. J. Arnold - M. S. Bjornlie - K. Sessa (eds.), A Companion to Ostrogothic Italy, Leiden - Boston 2016.

Arnold 2017: J. J. Arnold, Theoderic and Rome. Conquered but Unconquered, AntTard 25, 2017, 113-126.

Barnish 1992: S.J.B. Barnish (transl.), Selected Variae of Magnus Aurelius Cassiodorus Senator, Liverpool 1992.

Becker - Drocourt 2012: A. Becker - N. Drocourt (eds.), Ambassadeurs et ambassades au cœur des relations diplomatiques, Metz 2012.

Becker 2013: A. Becker, Les relations diplomatiques romano-barbares en Occident au Ve siècle: acteurs, fonctions, modalités, Paris 2013.

Becker 2018: A. Becker, Verbal and Nonverbal Diplomatic Communication at the Imperial Court of Constantinople (Fifth-Sixth Centuries), DOP 72, 2018, 79-92.

Biffi 2004: N. Biffi, L'ambasceria indiana ad Augusto del 20 a.C., InvLuc 26, 2004, 33-55.

Bjornlie 2013: M. S. Bjornlie, Politics and Tradition between Rome, Ravenna and Constantinople, Cambridge 2013.

Bjornlie 2014: M. S. Bjornlie, Law, Ethnicity and Taxes in Ostrogothic Italy: A Case for Continuity, Adaptation and Departure, EME 22, 2014, 138-170.

Bjornlie 2015: M. S. Bjornlie, The Rhetoric of Varietas and Epistolary Encyclopedism in the Variae of Cassiodorus, in: G. Greatrex - H. Elton (eds.), Shifting Genres in Late Antiquity, Farnham - Burlington 2015, 289-303.

Bjornlie 2019: M. S. Bjornlie (transl.), Cassiodorus. The Variae. The Complete Translation, Oakland 2019.

Blockley 1992: R. C. Blockley, East Roman Foreign Policy. Formation and Conduct from Diocletian to Anastasius, Leeds 1992.

Braccesi 2006: L. Braccesi, L’Alessandro occidentale. Il Macedone e Roma, Rome 2006.

Brodersen 2003: K. Brodersen, Terra cognita. Studien zur römischen Raumerfassung, Hildesheim - Zürich - New York 2003.

Burns 1978: T. Burns, Calculating Ostrogothic Population, AAntHung 26, 1978, 457-463.

Burns 1984: T. Burns, A History of the Ostrogoths, Bloomington - Indianapolis 1984.

Cristini 2017: M. Cristini, Il seguito ostrogoto di Amalafrida: confutazione di Procopio, Bellum Vandalicum I, 8, 12, Klio 99, 2017, 278-289.

Cristini 2018: M. Cristini, Teoderico e gli Esti: imitatio Augusti in Variae 5.2, Latomus 77, 2018, 207-210.

Cristini 2019a: M. Cristini, Concordia Theodericiana. De concordia in Latinis litteris Theoderici regis aetate conscriptis, Latomus 78, 2019, 314-333.

Cristini 2019b: M. Cristini, La 'libertas' nell'Italia del VI secolo, in: N. D’Acunto - E. Filippini (eds.), Libertas. Secoli X-XIII. Atti del Convegno Internazionale, Brescia, 14-16 settembre 2017, Milano 2019, 215-229.

Davidson - Schulz 1961: H.R.E. Davidson - W. Schulz, Die Warnenschwerter des Ostgotenkönigs Theoderich, Jahresschrift für mitteldeutsche Vorgeschichte 45, Halle 1961, 252-258.

Delaplace 2000: C. Delaplace, La “Guerre de Provence” (507-511), un épisode oublié de la domination ostrogothique en occident, in: Romanité et Cité Chrétienne: permanences et mutations, intégration et exclusion du ler au Vle siècle. Mélanges en l'Honneur d'Yvette Duval, Paris 2000, 77-89.

Deliyannis 2010: D. M. Deliyannis, The Mausoleum of Theoderic and the Seven Wonders of the World, Journal of Late Antiquity 3, 2010, 365-385. 
Devecka 2016: M. Devecka, White Elephant Gifts. Classicism in Ostrogothic Policy and in Variae 10.30, Journal of Late Antiquity 9, 2016, 195-217.

Favrod 1997: J. Favrod, Histoire politique du Royaume Burgonde (443-534), Lausanne 1997. Fratantuono - Smith 2018: L. M. Fratantuono - R. A. Smith, Virgil. Aeneid 8. Text, Translation, and Commentary, Leiden - Boston 2018.

Fridh 1973: Å. J. Fridh (ed.), Cassiodori Variarum libri XII, Turnhout 1973.

Gasti 2001: F. Gasti, Spunti in materia di naturalis historia nelle Variae di Cassiodoro, Cassiodorus 6-7, 2001, 133-150.

Giardina 2006: A. Giardina, Cassiodoro politico, Rome 2006.

Giardina 2012: A. Giardina, Cassiodoro, Teoderico e la porpora, in: A. De Vincentiis (ed.), Roma e il papato nel Medioevo. Studi in onore di Massimo Miglio II, Rome 2012, 43-62.

Giardina et al. 2014: A. Giardina - G. A. Cecconi - I. Tantillo (eds.), Flavio Magno Aurelio Cassiodoro Senatore. Varie II, Rome 2014.

Gillett 2003: A. Gillett, Envoys and Political Communication in the Late Antique West, 411-533, Cambridge 2003.

Gillett 2010: A. Gillett, Love and Grief in Post-Imperial Diplomacy. The Letters of Brunhild, in: B. Sidwell - D. Dzino (eds.), Power and Emotions in the Roman World and Late Antiquity, Piscataway 2010, 127-165.

Greatrex 2007: G. Greatrex, Roman Frontiers and Foreign Policy in the East, in: R. Alston S.N.C. Lieu (eds.), Aspects of the Roman East. Papers in Honour of Professor Fergus Millar FBA, Turnhout 2007, 103-173.

Harris 2003: A. Harris, Byzantium, Britain and the West. The Archaeology of Cultural Identity AD 400-650, Stroud - Charleston 2003.

Heather 1996: P. Heather, The Goths, Cambridge (MA) 1996.

Heather 2016: P. Heather, Review of M. S. Bjornlie. Politics and Tradition between Rome, Ravenna and Constantinople, EME 24, 2016, 369-372.

Hodgkin 1886: T. Hodgkin (transl.), The Letters of Cassiodorus, London 1886.

Hutton - Peterson 1970: M. Hutton - W. Peterson (transl.), Tacitus. Agricola, Germania, Dialogus, London - Cambridge (MA) 1970.

Johnson 1988: M. J. Johnson, Toward a History of Theoderic's Building Program, DOP 42, 1988, 73-96.

Jones 1962: A.H.M. Jones, The Constitutional Position of Odoacer and Theoderic, JRS 52, 1962, 126-130.

Kaldellis - Dewing 2014: A. Kaldellis - H. B. Dewing (transl.), Prokopios. The Wars of Justinian, Indianapolis - Cambridge 2014.

Kaldellis 2017: A. Kaldellis, Did the Byzantine Empire have "Ecumenical” or “Universal” Aspirations?, in: C. Ando - S. Richardson (eds.), Ancient States and Infrastructural Power. Europe, Asia, and America, Philadelphia 2017, 272-300.

Kienast 1969: D. Kienast, Augustus und Alexander, Gymnasium 76, 1969, 430-456.

Koehn 2018: C. Koehn, Justinian und die Armee des frühen Byzanz, Berlin - Boston 2018.

Kohlhas-Müller 1995: D. Kohlhas-Müller, Untersuchungen zur Rechtsstellung Theoderichs des Großen, Frankfurt a. Main 1995.

Kolendo 1993: J. Kolendo, L'ambra e i rapporti tra Cisalpina e regioni centro europee, Padova 1993.

König 1994: I. König, Die Herrschaftsbestätigung Theoderichs des Großen durch die Goten im Jahre 493, in: R. Günther - S. Rebenich (eds.), E fontibus haurire. Beiträge zur römischen Geschichte und zu ihren Hilfswissenschaften, Paderborn 1994, 147-161. 
Lanciotti 1986: F. Lanciotti, Lo "spazio romano" nella terminologia delle fonti giuridiche giustinianee in lingua latina, in: Popoli e spazio romano tra diritto e profezia, Naples 1986, 351-363.

La Rocca 2014: M. C. La Rocca, Mores tuos fabricae loquuntur. Building Activity and the Rhetoric of Power in Ostrogothic Italy, The Haskins Society Journal 26, 2014, 1-29.

La Rocca - Oppedisano 2016: A. La Rocca - F. Oppedisano, Il senato romano nell'Italia Ostrogota, Rome 2016.

Last 2013: H. Last, Die Außenpolitik Theoderichs des Großen, Norderstedt 2013.

Lobur 2008: J. A. Lobur, Consensus, Concordia and the Formation of Roman Imperial Ideology, New York - London 2008.

Lounghis 1980: T. C. Lounghis, Les ambassades byzantines en Occident depuis la fondation des états barbares jusqu'aux Croisades (407-1096), Athens 1980.

Mastino 1986: A. Mastino, Orbis, kosmos, oikoumene. Aspetti spaziali dell'idea di impero universale da Augusto a Teodosio, in: Popoli e spazio romano tra diritto e profezia, Naples 1986, 63-162.

Mehl 1994: A. Mehl, Imperium sine fine dedi. Die augusteische Vorstellung von der Grenzenlosigkeit des Römischen Reiches, in: E. Olshausen - H. Sonnabend (eds.), Stuttgarter Kolloquium zur historischen Geographie des Altertums IV (1990), Amsterdam 1994, 431-464.

Mierow 1915: C. C. Mierow (transl.), The Gothic History of Jordanes in English Version, Cambridge - New York 1915.

Minicucci 1983: A. Minicucci, De Vergilio apud Cassiodorum, RPL 6, 1983, 223-229.

Molè 1986: C. Molè, La terminologia dello spazio romano nelle fonti geografiche tardoantiche, in: Popoli e spazio romano tra diritto e profezia, Naples 1986, 321-350.

Mommsen 1894: T. Mommsen (ed.), Cassiodori Senatoris Variae, Berolini 1894.

Moorhead 1984: J. Moorhead, Theoderic, Zeno and Odovacer, ByzZ 77, 1984, 261-266.

Moorhead 1987: J. Moorhead, Libertas and nomen Romanorum in Ostrogothic Italy, Latomus 46, 1987, 161-168.

Moorhead 1992: J. Moorhead, Theoderic in Italy, Oxford 1992.

Nechaeva 2007: E. Nechaeva, Geography and Diplomacy. Journeys and Adventures of Late Antique Envoys, in: S. Conti - B. Scardigli - M. C. Torchio (eds.), Geografia e viaggi nell'antichità. Atti del Convegno Internazionale di Studi (Certosa di Pontignano, 9-10 ottobre 2005), Ancona 2007, 149-161.

Nechaeva 2014: E. Nechaeva, Embassies - Negotiations - Gifts. Systems of East Roman Diplomacy in Late Antiquity, Stuttgart 2014.

Nenci 1958: G. Nenci, L'imitatio Alexandri nelle Res gestae divi Augusti, in: G. Nenci, Introduzione alle Guerre Persiane e altri saggi di storia antica, Pisa 1958, 283-308.

Nickstadt 1921: H. Nickstadt, De digressionibus quibus in Variis usus est Cassiodorus, Marpurgi Chattorum 1921.

Noreña 2011: C. F. Noreña, Imperial Ideals in the Roman West. Representation, Circulation, Power, Cambridge 2011.

Obolensky 1961: D. Obolensky, The Principles and Methods of Byzantine Diplomacy, Belgrade 1961.

O’Sullivan 2016: L. O’Sullivan, Augustus and Alexander the Great at Athens, Phoenix 70, 2016, 339-360.

Peltonen 2019: J. Peltonen, Alexander the Great in the Roman Empire, 150 BC to AD 600, London - New York 2019. 
Pieroni 2011: P. Pieroni, Digressioni nelle Variae di Cassiodoro: ancora qualche considerazione, BStudLat 41, 2011, 543-555.

Pithou 1590: P. Pithou, Epigrammata et poematia vetera, Paris 1590.

Polara 1984: G. Polara, Cassiodoro, in: Enciclopedia Virgiliana I, Rome 1984, 691.

Prostko-Prostyński 1994: J. Prostko-Prostyński, Utraeque res publicae. The Emperor Anastasius l's Gothic Policy (491-518), Poznan 1994.

Rives 1999: J. B. Rives (transl.), Tacitus. Germania, Oxford 1999.

Rolfe 1979: J. C. Rolfe (transl.), Suetonius I, Cambridge (MA) 1979.

Romm 1992: J. S. Romm, The Edges of the Earth in Ancient Thought. Geography, Exploration and Fiction, Princeton 1992.

Rota 2001: S. Rota, Teoderico il Grande fra Graecia e Ausonia: la rappresentazione del re ostrogotico nel Panegyricus di Ennodio, MEFRM 113, 2001, 203-243.

Rushton Fairclough 1916-1918: H. Rushton Fairclough (transl.), Virgil, 2 vol., London - New York 1916-1918.

Saks 1960: E. V. Saks, Aestii. An Analysis of an Ancient European Civilization, Montreal Heidelberg 1960.

Sallmann 1998: N. Sallmann, De gloria sucini Baltici, RomBarb 15, 1998, 201-210.

Sarti 2017: L. Sarti, Totius terrae circulum oceani limbo circumseptum. Das Meer aus der Perspektive gotischer und langobardischer Historiographen, in:

G. Huber-Rebenich - C. Rohr - M. Stolz (eds.), Wasser in der mittelalterlichen Kultur. Gebrauch - Wahrnehmung - Symbolik, Berlin - Boston 2017, 78-89.

Schmid 1973: W. P. Schmid, s.v. Aisten, in: Reallexikon der germanischen Altertumskunde 1, 1973, 116-118.

Schmidt 1905: L. Schmidt, Geschichte der deutschen Stämme bis zum Ausgange der Völkerwanderung I.2-3, Berlin 1905.

Schreibelreiter 1989: G. Schreibelreiter, Vester est populus meus. Byzantinische Reichsideologie und germanisches Selbstverständnis, in: E. K. Chrysos - A. Schwarcz (eds.), Das Reich und die Barbaren, Wien - Köln 1989, 203-220.

Schwarcz 1993: A. Schwarcz, Die Restitutio Galliarum des Theoderich, in: Teoderico il Grande e i goti d'Italia. Atti del XIII Congresso Internazionale di studi sull'Alto Medioevo (Milano 2-6 novembre 1992) II, Spoleto 1993, 787-798.

Shanzer - Wood 2002: D. Shanzer - I. Wood (transl.), Avitus of Vienne, Letters and Selected Prose, Liverpool 2002.

Soraci 1974: R. Soraci, Aspetti di storia economica italiana nell'età di Cassiodoro, Catania 1974.

Spekke 1939: A. Spekke, Aistu sūtṇi pie Teodoríka Ravennā, in: M. Stepermanis et al. (eds.), Latviešu Vēsturnieku Veltijums Profesoram Dr. Hist. Robertam Viperam, Riga 1939, 294-326.

Spekke 1976: A. Spekke, The Ancient Amber Routes and the Geographical Discovery of the Eastern Baltic, Chicago 1976.

Springer 2006: M. Springer, Warnen, in: Reallexikon der germanischen Altertumskunde 33, 2006, 274-281.

Staab 1976: F. Staab, Ostrogothic Geographers at the Court of Theoderic the Great. A Study of Some Sources of the Anonymous Cosmographer of Ravenna, Viator 7, 1976, 27-58.

Steinacher 2016: R. Steinacher, Die Vandalen. Aufstieg und Fall eines Barbarenreichs, Stuttgart 2016.

Suerbaum 1961: W. Suerbaum, Vom antiken zum frühmittelalterlichen Staatsbegriff, Münster 1961. 
Talbert 1990: R.J.A. Talbert, Rome's Empire and Beyond. The Spatial Aspect, CEA 26, 1990, 215-223.

Tanzi 1887: C. Tanzi, Studio sulla cronologia dei libri Variarum di Cassiodoro Senatore, Archeografo Triestino 13, 1887, 1-36.

Thompson 1982: E. A. Thompson, Romans and Barbarians. The Decline of the Western Empire, Madison - London 1982.

Van Hoof - Van Nuffelen 2017: L. Van Hoof - P. Van Nuffelen, The Historiography of Crisis. Jordanes, Cassiodorus and Justinian in Mid-Sixth-Century Constantinople, JRS 107, 2017, 275-300.

Van Nuffelen 2019: P. Van Nuffelen, Beside the Rim of the Ocean. The Edges of the World in Fifth- and Sixth-Century Historiography, in: P. Van Nuffelen (ed.), Historiography and Space in Late Antiquity, Cambridge 2019, 36-56.

Vera 2016: D. Vera, Signum dei o signum deae nel panegirico del 313? Constantino, l'imitatio Augusti e l'Italia istituzionale nel IV secolo, AntTard 24, 2016, 391-409.

Viscido 1991: L. Viscido, De Vergilio apud Cassiodorum adnotationes quaedam, VoxLat 27, 1991, 214-218.

Vitiello 2015: M. Vitiello, Blaming the Late Republic. Senatorial Ideology and Republican Institutions in Late Antiquity, Classical Receptions Journal 7, 2015, 31-45.

Vogt 1960: J. Vogt, Orbis Romanus. Ein Beitrag zum Sprachgebrauch und zur Vorstellungswelt des römischen Imperialismus, in: J. Vogt, Orbis. Ausgewählte Schriften zur Geschichte des Altertums, Freiburg - Basel - Wien 1960, 151-171.

Wallace 2018: S. Wallace, Metalexandron. Receptions of Alexander in the Hellenistic and Roman Worlds, in: K. R. Moore (ed.), Brill's Companion to the Reception of Alexander the Great, Leiden - Boston 2018, 162-196.

Wiemer 2013: H. U. Wiemer, review of M. S. Bjornlie. Politics and Tradition between Rome, Ravenna and Constantinople, Sehepunkte 13.11, 2013, http://www.sehepunkte. de/2013/11/22995.html, accessed 13 February 2021.

Wiemer 2018: H. U. Wiemer, Theoderich der Grosse König der Goten - Herrscher der Römer. Eine Biographie, München 2018.

Wolfram 1989: H. Wolfram, s.v. Ermanarich, in: Reallexicon der Germanischen Altertumskunde 7, 1989, 510-515.

Wolfram 2009: H. Wolfram, Die Goten. Von den Anfängen bis zur Mitte des sechsten Jahrhunderts. Entwurf einer historischen Ethnographie, München $2009^{5}$.

Wood 2014: I. Wood, The Burgundians and Byzantium, in: A. Fischer - I. Wood (eds.), Western Perspectives on the Mediterranean. Cultural Transfer in Late Antiquity and the Early Middle Ages, 400-800 AD, London 2014, 1-15. 